THE INFLUENCE OF THE REGIONAL STRUCTURE OF THE RHODESIA CRATON ON THE DISTRIBUTION OF KIMBERLITES IN BOTSWANA AND ZIMBABWE

\title{
D.A. Pretorius
}

Economic Geology Research Unit, University of the Witwatersrand 1 Jan Smuts Avenue, 2001 Johannesburg, South Africa

Alluvial diamonds were discovered in 1903 in what was then Southern Rhodesia. In the following ten years, search for the sources of these Somabula diamonds resulted in the discovery of the Colossus kimberlite field housing four pipes and one kimberlitic sill and the Clare Field containing six pipes, one sill, and one fissure (Fig. 1). Later prospecting resulted in the finding of nine further kimberlitic bodies, bringing the total so far located up to 22 , six of which have been proved to contain diamonds. Of these six, only one, the River Ranch pipe, is of possible economic interest. Up to the end of 1979, the total recorded production of diamonds from Zimbabwe was a relatively-insignificant 20000 carats, of which 95 per cent had been recovered from the Somabula Field, in which the alluvial diamonds have been derived from the weathering and reworking of detrital stones in Karoo-age sediments (Table I).

Exploration in Zimbabwe led to the conclusion that its potential for economically-viable deposits of diamonds was poor. In the latter half of the 1960's, very significant discoveries of diamondiferous kimberlites were made south of the Makgadikgadi Pans in Botswana, to the southwest of the region containing the Somabula, Colossus, and Clare fields. Consequent investigations culminated in the delineation of the Orapa kimberlite field, containing two productive pipes, Orapa and Letlhakane, out of a total of, at least, 29 kimberlitic bodies. Production from the first-rank Orapa pipe commenced in 1971 and, to the end of 1985, a little under 50 million carats had been recovered. The lesser Letlhakane pipe started producing in 1977 and had yielded over 4 million carats to the end of 1985 (Table I).

The limited exposures of the Precambrian rocks in northeastern Botswana indicate that this segment of the territory is an integral part of the long-recognized Rhodesia Craton of which the classic Archean granite-greenstone terrane of the central region of Zimbabwe constitutes the shield. The investigations, the results of which are summarized in this abstract, have had as their goals : (i) the definition of the extent and geometry of the Rhodesia Craton; (ii) the identification of the distribution pattern, if any, of kimberlites on the craton; and (iii) the delineation of structural controls, if any, on the localization of the Orapa, Colossus, Clare, and other kimberlite fields.

The tectonic nuclei of Southern Africa are constituted by the Kaapvaal and Rhodesia cratons in which Archean granite-greenstone basements are exposed. These cratons are surrounded by centripetally-overthrust terranes in which the oldest, regional, metamorphic imprints are of the order of $2000 \mathrm{Ma}$. Kimberlites occur in equal abundance in cratonic and overthrust terranes, but diamond-bearing varieties are preferentially developed on the cratons, where they are present in both the shield and the platform regions. Up to 1970, diamond production came essentially from the Kaapval Craton, with comparatively very small quantities only emanating from the Rhodesia Craton. Discoveries in Botswana, within the last two decades, have resulted in substantial changes in the distribution-patterns of production.

Gravimetric, aeromagnetic, and borehole-drilling investigations, carried out in Botswana in the past ten years have contributed substantially to an unravelling of the subsurface geology and structure beneath the extensive cover of Quaternary Kalahari formations in the central segment of Southern Africa. As a result, it is now possible to define the boundaries of the Rhodesia Craton, its extent and shape, and its first-order structures. This crustal fragment is a classic chelonic craton, ovoid in shape, with a long axis at least $1500 \mathrm{~km}$ long, in a northeasterly direction, and a short axis of the order of $600 \mathrm{~km}$ long, in a northwesterly direction. It is distinctly asymmetrical, along the northeasterly axis, about the point of maximum tectonic elevation of the craton, with the longer segment of the axis extending southwestwards from central Zimbabwe into central Botswana. 


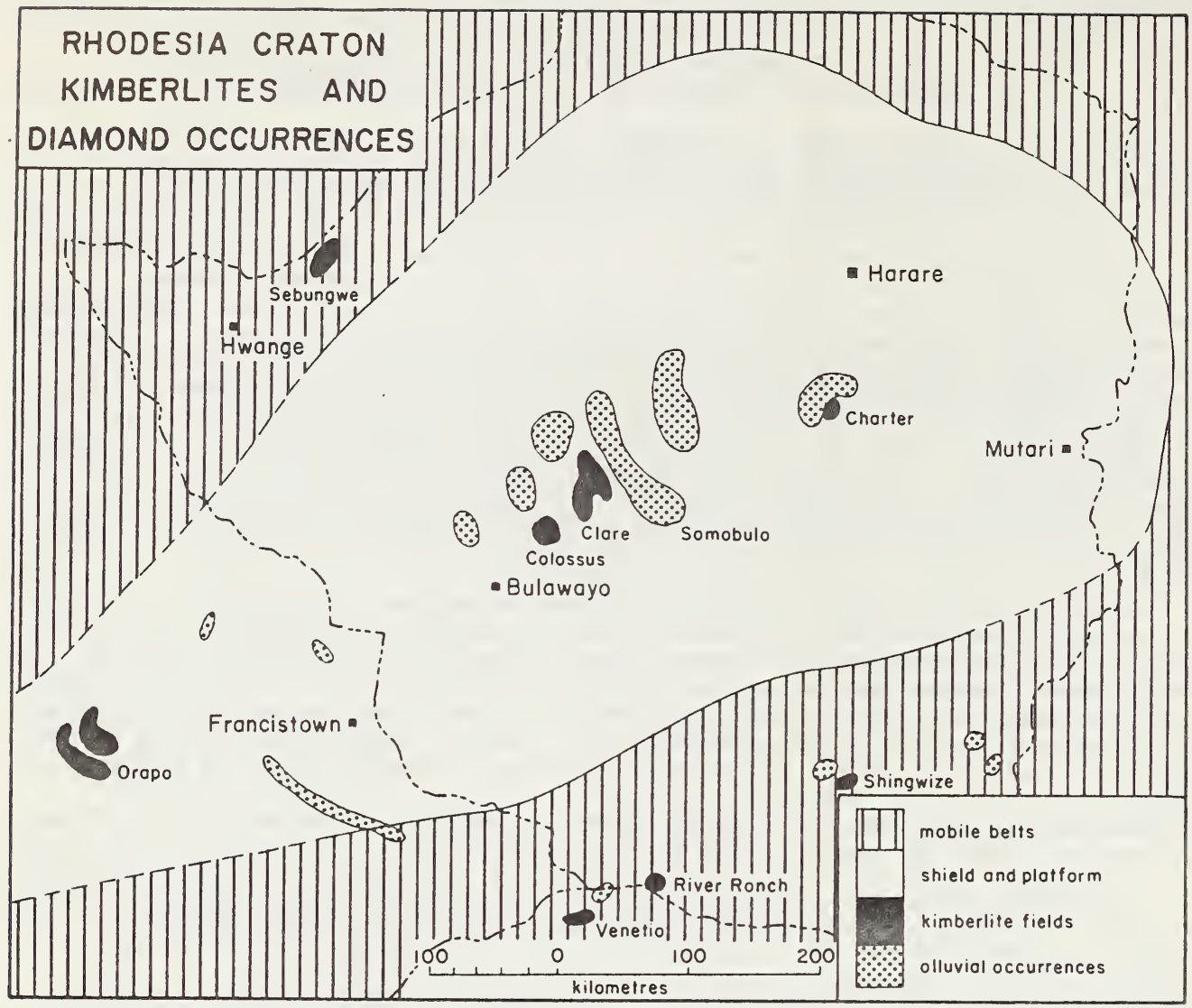

Figure 1 : The shield and platform of the Rhodesia Craton, with their enveloping mobile belts of metamorphic terrane. Kimberlite fields are aligned along ENE-to-NE trends along the spine of the craton and on the northeastern flanks.

TABLE I

DIAMOND PRODUCTION FROM THE RHODESIA CRATON

ZIMBABWE AND BOTSWANA : 1905-1985

\begin{tabular}{|l|l|r|}
\hline Country & Source of Diamonds & \multicolumn{1}{|c|}{ Carats } \\
\hline Botswana & Orapa Pipe & 49878839 \\
Botswana & Letlhakane Pipe & 4160389 \\
Zimbabwe & Somabula Alluvials & 19185 \\
Zimbabwe & Colossus Pipe & 144 \\
Zimbabwe & Wessels Sill & 81 \\
Zimbabwe & 0ther Sources & 227 \\
\hline \multicolumn{2}{|l|}{ Total Production from Rhodesia Craton } & 54058865 \\
\hline
\end{tabular}


The Rhodesia chelonic craton shows a typical concentric pattern of alternating upwarps and downwarps wrapping around the point of maximum tectonic elevation. The upwarps are characterized by gravity lows and the downwarps by gravity highs, indicative of uplifted and depressed Archean granitic basement, respectively. The aeromagnetic field over Botswana also clearly indicates a curvilinear fabric on the southwestern portion of the craton, concave towards the central region of Zimbabwe.

Kimberlites are sporadically distributed over the whole of the Rhodesia Craton, but there is a distinctly greater number on the longer southwestern segment of the crustal fragment. Diamond-bearing pipes also are known only within the western portion of the craton. Because of the turtle-backed shape of the chelonic craton, there is a quaquaversal regional plunge radially away from the point of maximum tectonic elevation. As there is progressively decreasing uplift down the regional plunge, the degree of erosion of kimberlite pipes also diminishes down the plunge. Consequently, factors responsible for the development of larger volumes of alluvial diamonds become less favourable from central and southwestern Zimbabwe into central Botswana, while factors inclining towards the preservation of the uppermost portions of pipes are enhanced along the same trend.

Kimberlite pipes were preferentially intruded along upwarps, distinguished by elevated basement and gravity lows. In addition to the concentric upwarps, the northeasterly-trending spine of the chelonic craton also represents an axis of extensive arching. Four clusters of diamond-bearing kimberlite pipes - Orapa in Botswana and Colossus, Clare, and Charter in Zimbabwe - are located on the spinal upwarp, where this is intersected by different concentric upwarps. Other diamondiferous clusters, such as River Ranch in southern Zimbabwe and Venetia in the northwestern Transvaal occur on concentric upwarps. Employing concepts developed from these structural observations, a target-area was selected in east-central Botswana, in which subsequent exploration has indicated the presence of the Gope 25 diamond-bearing kimberlite pipe. 